\title{
Esping-Andersen'in Refah Devleti Sınıflandırması ve Makro Sosyal Hizmet Uygulamaları Temelinde Türkiye'nin Konumu
}

\author{
DOI: 10.26466/opus.542395 \\ * \\ Buğra Yıldırım* - Fatih Şahin** \\ *Dr. Öğr. Üyesi, Manisa Celal Bayar Üni., Sağlık Bil. Fak., Sosyal Hizmet Böl., Manisa/ Türkiye \\ E-Posta: bugra.yildirim@cbu.edu.tr \\ ORCID: 0000-0002-2840-3624 \\ ** Prof.Dr., Manisa Celal Bayar Üni., Sağlık Bil. Fak., Sosyal Hizmet Böl., Manisa/ Türkiye \\ E-Posta: fatih.sahin@cbu.edu.tr \\ ORCID: $\underline{0000-0003-4171-0722}$
}

Öz

Sosyal çevre içindeki bireylerin sosyal sorunlarına yönelik politikalar, toplumun değişimi, gelişmesi için kolektif bir biçimde yapılan düzenlemeler makro sosyal hizmet uygulamalarıdır. Makro sosyal hizmet uygulamaları, her ülkenin kendine özgü sosyopolitik ve kültürel dinamikleri içerisinde farkh şekillerde yoğrulmaktadır. Sosyal hizmet uzmanlarının makro uygulama gerçekleştirebilmesi için sosyal politika bilgisinin mutlaka olması gerekir. Bu bağlamda Türkiye'nin hangi refah refiminde yer aldığını bilmeden, benzediğimiz ülkeleri ve ortak özellikleri anlamadan yola çıkmamız pek doğru bir tercih olmayacaktır. Dahası, insan ihtiyaçları arttıkça, çeşitlendikçe refah devletiyle kucaklaşma isteği de artacaktır. Refah devleti tabiri bir yandan güçlü, zengin ülkeleri simgelerken bir yandan da vatandaşlarma sosyal haklarl, sosyal politikalar üst düzeyde sunan devletleri ifade etmektedir. Bugün bilim çevrelerince en çok kabul gören, eleştirilen ve referans alınan başvuru kaynağı Esping-Andersen'in refah devleti sinıflandırmasıdır. Esping-Andersen'in refah rejimi, piyasayı, aile pratiklerini ve sosyal tabakalaşmayı göz önünde bulundurarak refah devletlerini sinıflandırmaktadır. Çalışma bu yönüyle Esping-Andersen'in refah devleti sınıflandırmasını ana hatlar ile özetleme amacı taşımaktır. Diğer taraftan Türkiye'nin refah devletleri arasındaki pozisyonunu makro sosyal hizmet uygulamaları açısından açıklama isteği de bu çalışmanın başlıca kaygısıdır. Sosyal hizmet mesleği, sosyal refah alanı içerisinde gelişmiş bir meslek ve disiplindir. Bu anlamda sosyal hizmetler, vatandaşın sosyal işlevsellikle ilgili sorun ve ihtiyaçlarına yönelen genellikle kamusal nitelikli hizmetler olup sosyal refah politikalart ile makro düzeyde ele alnabilir. İlerleyen yillarda sosyal hizmet alaninda refah devleti ve sosyal politika konuları ile ilgili kapsaml çalışmaların yapılacağı düşünülmektedir.

Anahtar Kelimeler: Makro sosyal hizmet uygulamaları, Sosyal hizmet uzmanları, Refah devleti, Esping-Andersen'in refah devleti sinıflandırması. 


\title{
Esping-Andersen's Welfare State Classification and Turkey's Position of Based on Macro Social Work Practices
}

\begin{abstract}
Policies regarding the social problems of individuals in the social environment, collective regulations for the change and development of society are macro social work practices. Macro social work practices are interpreted in different forms within each country's specific sociopolitical and cultural dynamics. In order for social workers to implement macro practices, they must have social policy knowledge. In this context, it would not be the right choice to take action without knowing which welfare regime Turkey falls within and without understanding the similar countries and the common characteristics. Moreover, as human needs increase and diversify, the desire to embrace the welfare state will also increase. The term welfare state, on the one hand, stands for strong and wealthy countries, and on the other hand, refers to states that offer social rights and social policies to its citizens at a high level. Nowadays, the most accepted, criticized and referenced source by the scientific circles is Esping-Andersen's welfare state classification. Esping-Andersen classified the social stratification in terms of the common characteristics of welfare states by taking market and family practices as a basis. In this respect, the study aims to summarize Esping-Andersen's welfare state classification in general terms. On the other hand, the desire to explain Turkey's position among the welfare states in terms of macro social work practices is the main concern of this study. The social work profession is an advanced profession and discipline within the social welfare field. In this sense, social services are generally public services oriented towards the problems and needs of the citizens regarding social functionality and can be discussed at the macro level with social welfare policies. In the following years, it is thought that comprehensive studies will be carried out on the welfare state and social policy in the social work field. In this study, it is aimed to scale university students' leisure time activities.
\end{abstract}

Keywords: Macro social work practices, Social workers, Welfare state, Esping-Andersen's welfare state classification. 


\section{Giriş}

Sosyal çevre içindeki bireylerin sosyal sorunlarına yönelik politikalar, toplumun değişimi, gelişmesi için kolektif bir biçimde yapılan düzenlemeler makro sosyal hizmet uygulamalarıdır. Makro uygulama daha geniş bir bakış açısı sunmak için sosyal politika kurumları ile birlikte çalışmayı kapsar. Sosyal politika yapıcılarla birlikte çalışmanın koşulu da, kurum ve program yönetimi, politika üretme, toplum örgütlenmesiyle ilgili bilgi ve becerileri içerir (Austin, Coombs ve Barr, 2005; Keçeci, 2017). İşsizlik, yoksulluk, adaletsizlik ve eşitsizlik gibi sosyal sorunlara karşı gerçekleştirilebilecek tüm sosyal hizmet müdahale ve uygulamaları, birey odaklı psikososyal süreçlerden ve klinik uygulamalardan sosyal planlama, sosyal kalkınma ve sosyal politikaya kadar uzanmaktadır (Demirbilek, 2009, s.92). Diğer bir ifadeyle makro düzeyde sosyal değişmeyi sağlamak için sosyal politikalara etkinizin, politika süreçlerine de katılımınızın olmasi gerekmektedir.

Makro sosyal hizmet uygulamaları, her ülkenin kendine özgü sosyopolitik ve kültürel dinamikleri içerisinde farklı şekillerde yoğrulmaktadır. Ekonomik krizler, modernleşme, kentleşme, sanayileşme, dünya savaşları vb. tecrübelerin topluma yaşattığı olumsuz etkilerin yok edilmeye çalışılması, makro sosyal hizmet müdahalesinin kuram ve uygulaması adına kayda değer değişkenler olmuştur (Keçeci, 2017). Eğer sosyal hizmet uzmanı iseniz, hizmet verdiğiniz toplumun sorunlarından ve dinamiğinden uzaklaşmamanız gerekir. Toplumsal dinamiklerden koparsanız nitelikli bir hizmet sunumu gerçekleştiremezsiniz. Sosyal hizmet uzmanlarının makro uygulama gerçekleştirebilmesi için sosyal politika bilgisinin mutlaka olması gerekir. Bu bağlamda Türkiye'nin hangi refah rejiminde yer aldığını bilmeden, benzediğimiz ülkeleri ve ortak özellikleri anlamadan yola çıkmamız pek doğru bir tercih olmayacaktır.

Sosyal politika, sosyal sorunları inceleyen ve sorun alanlarına makro bakış açısıyla çözümler öneren bir kavrayışa sahiptir. Refahı ve esenliğini sağlamak amaciyla toplum içinde insanlara hizmet geliştirip sunar ve insanların ihtiyaçlarını karşılar (Alcock ve May, 2014). Sosyal politika, bir toplumu meydana getiren çeşitli sosyal sınıfların durumlarını, hareketlerini, birbiriyle ilişkilerini, çatışma ve mücadelelerini ele alarak devleti korumaya ve toplumu huzura, istikrara ve refaha kavuşturmaya yönelik 
tedbirleri, usul ve esasları inceleyen bir disiplindir. Devletin başlıca sosyal politika araçları kamu hizmetleri, sosyal sigortalar, sosyal teşvik, sosyal tanzim, sosyal yardım ve sosyal hizmetleri kapsar. Dar anlamda sosyal politika anlayışı ile ilgili olan sosyal politika araçları; muhtaç, yoksul ve güçsüz konumda olan bireyleri sosyal devlet üzerinden koruma alışkanlığı sergilerken üretim mekanizmalarındaki fertlerin, çalışanların statüsünü iyileştirme ve tüm topluma güvenli gelecek sağlama amaçlarına sahiptir.

Sosyal politika araçlarının geniş anlamı ise en kapsayıcı açıklamasıyla toplumsal refahı yükseltmek için devletin ulaşmak istediği genel amaçları işaret etmektedir. Mali büyümeden fiyatlardaki dalgalanmanın önlenmesine, bilânço ve üretim dengesinden nitelikli kaynak teminine kadar akla gelebilecek her alanı ve bütün uygulamaları içerir. Bireysel ve toplu iş hukuku, çalışma yasaları, işçi sağlığı ve iş güvenliği, ücretler, gelir dağılımı, ücretli istihdam ilişkilerinin dışında kalan kadın, çocuk, aile gibi kimi grupların refahı ve eğitim, sağlık, barınma gibi alanlara dönük bir genişlemeyi kapsar. Geniş anlamda sosyal politika düşüncesi bütün bireylerin ihtiyaçlarını karşılamaya odaklandığı gibi devletin varlığını korumayı ve sürekliliğini sağlamayı da aklından çıkarmaz. Vatandaşlar, gruplar, sivil toplum, devletler ve devlet dışındaki aktörler ile arasındaki ilişkileri tanımlar. Böylece sosyal politika kalemleri de yavaş yavaş çeşitlilik arz eder. Artık sıra refah devletine geçişe gelmiştir.

Mishra (1999), refah devletine yönelik en önemli gelişmelerin özellikle II. Dünya Savaşı'ndan sonra sosyal politika ve sosyal refahla ilgili temel düşünce ve varsayımların tekrar gözden geçirilmesi ile ortaya çıtığını açıklar. Böylece derin yıkımlar ve felaketler geçirdikçe insanlık yeniden gelişmeye, hatta ayağa kalkmaya çalışacaktır. İnsan ihtiyaçları arttıkça, çeşitlendikçe refah devletiyle kucaklaşma isteği de artacaktır. Refah devleti tabiri bir yandan güçlü, zengin ülkeleri simgelerken bir yandan da vatandaşlarına sosyal hakları, sosyal politikaları üst düzey sunan devletleri ifade etmektedir. Ancak refah devletlerinin vatandaşlarına yönelik uygulamaya koyduğu sosyal hakların ve politikaların sunum şekli ile mantığı, bu devletleri ortak özellikleri açısından sınıflandırma zorunluluğunu doğurmuştur.

Esping-Andersen (1990)'in refah devleti sınıflandırması bugün bilim çevrelerince en çok kabul gören, eleştirilen ve referans alınan başvuru 
kaynağıdır. Sosyal haklar, sosyal politikalar, lobicilik, savunuculuk, politika yapıcılık, toplum örgütlenmesi, makro uygulama vb. kavramları mesleki terminolojide sıkça kullanan sosyal hizmet uzmanlarının refah devleti teması üzerine kurulan bu temel sınıflandırmaya hâkim olmaları gerekmektedir. Devlet ve piyasa gibi refah sağlayan ana kurumların bakış açılarının makro düzey uygulama yapan sosyal hizmet uzmanları tarafından özümsenmesi önemlidir. Çalışma bu yönüyle Esping-Andersen' in refah devleti sınıflandırmasını ana hatları ile özetleme amacı taşımaktır. Diğer taraftan Türkiye'nin refah devletleri arasındaki pozisyonunu makro sosyal hizmet uygulamaları açısından açılama isteği de bu çalışmanın başlıca kaygısıdır.

\section{Esping-Andersen'in Refah Devletleri Sınıflandırması}

Esping-Andersen refah rejimlerini üçlü bir sinıflandırmaya tabi tutarak refah devletlerini birbirinden ayırmaktadır. Sınıflandırmaya göre devletler, Liberal veya Piyasa Merkezli Refah Rejimine, Muhafazakâr veya Kita Avrupası Refah Rejimine (Korporatist), Sosyal Demokrat veya İskandinav Refah Rejimi'ne tabidir.

Esping-Andersen'in üçlü refah rejimi sınıflandırmasındaki ayrım modele giren devletlerin ortak özelliklerinde yatmaktadır. Birbiri ile ortak noktalara ve benzer sosyal politika felsefesine sahip ülkeler aynı refah rejiminin içinde yer almaktadır. Andersen'in sınıflandırmasını daha özel yönleri ile açıklayan Özdemir (2004)'e göre sosyal demokratik refah refimi, Kuzey Avrupa ülkelerinde yaygın olup eğitim, sağlık ve çalışma gibi temel insan haklarını piyasa ilişkilerinden ayrı tutmaya çalışmaktadır. Bu ülkelerde vatandaşların hak talepleri evrensel bir sisteme tabidir. Kita Avrupası'nda ise refah devleti muhafazakâr özellikler gösteren, korporatist bir sistemdir. Piyasadan meta-dışılaştırılamayan ${ }^{1}$ sosyal haklara rağmen, sosyal piyasa ekonomisi tarzı ile piyasanın sınırlı bir eleştirisini

\footnotetext{
1 Ingilizcesi dekomodifikasyon olan kavramın karşıtı komodifikasyondur. "Meta-dışılaştırma"; bireylerin piyasadan bağımsız olarak hareket edebilme ve sosyal açıdan kabul edilebilir bir yaşam standardını gerçekleştirebilme kabiliyeti olarak tanımlabilir. Sosyal hakların en fazla kurumsallaştığı ve piyasa dışından sağlandığı politika çercevesidir. "Meta-dışılaştırma" için önemli husulardan biri; hizmetlerin, yaşam ve geçim idamesinin piyasaya katılımdan bağımsızlaşması ve sosyal yararın piyasa vasıtasıyla erişilebilirlik derecesinin önem kazanmasıdır. Sosyal haklar bu politik bakış açısıyla meta olmaktan çıkar ve devlet ya da hükümetler tarafından sağlanır.
} 
içermektedir. Varlık araştırması ve sigorta sistemine dayanarak evrensel bir sistemi tercih etmez. Sosyal eşitsizlikler üretmeye eğilimlidir ancak piyasanın risklerinden korunmayı da beraberinde getirir. Azda olsa piyasa risklerinden sistematik korunma sağlaması bir avantaj olarak değerlendirilebilir. Anglo Amerikan demokrasilerin liberal modeli ise, piyasadan kaynaklanabilecek olumsuz sonuçlara bariyer olmayı hedefler, örgütlü refah oluşumlarının özel bir anlayışıdır ve basit tanımlamasıyla klasik yoksulluk yasalarının uzantısıdır (Özdemir, 2004).

Esping-Andersen (1990)'e göre, refah rejimleri arasındaki en temel farklılıklar, sosyopolitik bu üç geleneğin örüntüsüdür. Kalıntı (residual) bir refah devleti anlayışını benimseyenler liberal görüş sahipleridir. Yani devlet, bireysel tercihleri ve çalışma arzusu olanları sınırlandırarak piyasaların özgür ruhuna müdahale etmemelidir. Parasal destekleme anlayışını (subsidiarity) muhafazakâr görüştekiler; evrensel (universal) ve yeniden dağıtıcı (redistributive) bir refah devleti anlayışını ise sosyal demokrat görüştekiler ön planda tutmaktadır (Ebbinghaus ve Manow, 2004; Özdemir, 2004; Titmuss, 1974).

Liberal refah devleti, piyasadan elde edilen kazançlara ve kişisel kendine yardım mekanizmalarına müdahalede bulunmamak adına tüm bireylere göreceli bir biçimde düşük olasılıklı faydalar sağlamakta, dolayısıyla meta-dışılaştırmanın etkisini düşük düzeyde tutmaktadır. Muhafazakâr refah devletlerinde ise meta-dışılaştırma orta düzeydedir. $\mathrm{Bu}$ devletler, genellikle katkıya ve istihdama dayalı geniş sosyal transfer ödemelerini değişik sosyal ya da mesleki gruplara sağlamaktadır. Son olarak İskandinav refah devletlerinin doğuşu da sosyal demokratik işçi hareketlerinin bütün vatandaşlara evrensel sosyal yararlar ve geniş tabanlı kamu hizmetleri sağlamasıyla şekillenmiştir (Aydın ve Çakmak, 2017; Toprak, 2015; Özdemir, 2004; Esping-Andersen, 1996; Esping-Andersen, 1990).

Makalede Esping-Andersen'in üçlü sinıflandırmasının temel özellikleri tartışılacak, daha sonra bu sınıflandırma girişimine yönelik çeşitli eleştiri ve katkılara yer verilerek Türkiye'nin de dâhil olduğu Güney Avrupa Refah Devleti Modeli ele alınacaktır. 


\section{Liberal Refah Rejimi}

Bu refah rejimini Anglo-Sankson ya da Anglo-Amerikan model olarak adlandırmak mümkündür. Temel prensip, piyasa mantığına göre hareket etmektir. Genelde bağlı olduğu gelir araştırmasını göz önünde bulundurur ve hizmetlerden yararlananları damgalayıcı özellik sergiler. Devlet vatandaşa asgari düzeyde yarar sağlar. Özdemir (2004)'e göre liberal refah rejimindeki devletlerin eğilimi, daha az harcama kalemlerinin daha az planlanması yönünde olup, Avusturalya, ABD ve Kanada bu modelin önde gelen örnekleridir. Bir dereceye kadar Yeni Zelanda ve İngiltere de liberal refah rejiminde yer alır.

$\mathrm{Bu}$ devletlerde piyasa aktörleri esas itibarıla vatandaşlardır. Vatandaşlar kendi refahlarını piyasada aramaları yönünde koşullanır ve piyasa üzerinden sosyal hakları iyileştirme konusunda yoğun bir isteksizlik söz konusudur. En son çare başvuru mercii devlettir ve gelir transferi yine devlet tarafından ciddi anlamda en kötü çıktılar neticesinde vatandaşa sunulur. Dolayısıyla sosyal sigorta yararları mütevazı ölçekli iken temel sosyal yardım programları vatandaşlar tarafından gelir araştırmasına başvurulmadan işlerlik kazanmamaktadır. Bu ülkeler muhafazakâr ülkelerde olduğu gibi ne tamamen sosyal sorunları giderme/önleme/tanzim etme amacına sahiptir ne de İskandinav ülkelerinde olduğu gibi istihdam sağlamayı ön planda tutmaktadır. Piyasayla birlikte dini ve gönüllü organizasyonların etkin bir role sahip olduğu ve varlıklı gruplara özel şartlar sunulmasına izin veren sosyal programları içeren bu modelde her yol tüketildikten sonra hâlâ sosyal sorunlarla baş edemeyenlerin başvuracağı son kale devlettir (Aslan 2017; Aydın ve Çakmak, 2017; Zengin ve Altındağ, 2013; Gökbunar, Özdemir ve Uğur, 2008; Esping-Andersen, 2002; Myles ve Quadagno, 2002; Esping-Andersen, 1994).

Liberal ülkelerde, kamu sektörü istihdamı daha düşüktür. OECD ortalamasının üzerinde ise özel sektör istihdamının bulunduğu görülmektedir. Vergiler düşük düzeyli olup, kadınların iş gücüne katılım oranları görece daha yüksektir (Toprak, 2015; Özdemir, 2004). Sınırlı refah devleti özellikleri gösterdikleri için herhangi bir finansal kriz ya da finansman yokluğu ile karşılaşmamaktadırlar. İyiden iyiye sendikaların güç kaybı yaşadığı bu ülkelerde, gelir dağılımında adaletsizlik ve maaşlar 
arasında orta ya da yüksek ölçekli uçurumlar gözlenmektedir. Temel sıkıntıları ise artan yoksulluk ve sosyal eşitsizliktir. Bu modelde sosyal refah programları yalnızca asgari gelir garantisi sağlamaktadır ve sınırlı bir düzeyde müdahalede bulunmaktadır. Bu nedenle liberal model zaman zaman "gece bekçisi devlet" olarak nitelendirilmektedir (Özdemir, 2004; Myles ve Quadagno, 2002; Marangoz, 2001, s. 103-104).

Liberal refah rejimi, piyasa çözümlerine yönelmekte, özel refah önlemlerini norm olarak teşvik etmekte, piyasa başarısızlıklarında kamunun sorumluluğunu sınırlandırmaktadır. Çalışma yaşamı dışında kalan insanlara yönelik sosyal refah hizmetleri, ancak muhtaç olup olmadıklarının araştırılması sonucunda söz konusu olabilmekte, böylelikle bu bireylere yarar sunmayı amaçlayan kalıntı bir anlayış benimsenmektedir (EspingAndersen, 2002; Mishra, 1999).

\section{Muhafazakâr veya Kıta Avrupası Refah Rejimi}

Avusturya, Almanya, Fransa, İtalya'nın bir bölümü (özellikle güneyi hariç) ve Belçika bu refah rejimine örnek sistemlere sahiptir. Almanya genellikle bu türle ilgili değerlendirmelerde önde gelir. Kita Avrupası Refah Rejimi'ne; Sosyal Sigortalar Modeli, Bismark Ülkeleri Modeli, Korporatist Refah Rejimi de denir (Özdemir, 2004; Sözer, 1997). Geçmişten miras kalan hiyerarşik sosyal düzeni korumakla yakinen ilgilidir, sosyal düzene oranla piyasanın verimliliğini daha az önemser ve anti-liberaldir (Spicker, 2000). Marjinal ölçekli özel refah düzenlemelerinin ${ }^{2}$ rolü söz konusudur ve hakların sosyal boyutu geniştir (Vesali ve Omidi, 2014; Özdemir, 2004; Spicker, 2000).

Diğer yandan bu refah devletindeki ülkeler korporatistir ${ }^{3}$ çünkü köklerine bakıldığında ayrıcalıklar ve haklar statü ve sınıf bazında ayrışır, hatta gelirin yeniden dağılımı da marjinal ölçekte seyreder. Bu devletler

\footnotetext{
2 Özel refah düzenlemeleri, sosyal devletin görevlerinin önemli bir bölümünün piyasa koşullarına veya düzenlemelerine terk edilmesidir. Özel hizmet üreten kesimin sosyal duyarlılı̆ının geliştirilmesi, sivil toplum kuruluşlarının sosyal konulara özendirilmesi yine özel refah düzenlemeleri arasında yer alır.

${ }^{3}$ Kilise veya dini kurumların bakış açıları etkilidir ve muhafazakâr bir duruş genellikle bulunur. Örneğin korporatist oluşumlara herkes kabul edilmez. Korparatist algı, statü üyeliğine göre sınıflanır. Üretim sınıfları veya meslekler üzerinden tanımlanan dışa kapalı bir sosyal grup oluşumudur. Sermayeyi destekler. Özel mülkiyet ve bireysel girişimleri toplum düzeni saymakla birlikte katı devlet kontrolünün de bulunduğu anti-liberal ekonomik görüştür. Ayrıca orta çağdan beri var olan bir iş rejimidir.
} 
devlet yardımı prensibi üzerine bir yandan vurgu yaparken öte taraftan öncelik olarak piyasayı ikinci plana atan ve sosyal refah merkezi olarak aileyi esas alan Hristiyan Demokratik (Katoliklerdeki gibi) doktrinlerden güçlü bir şekilde etkilenmiştir (Aydın ve Çakmak, 2017; Gökbunar vd., 2008; Özdemir, 2004). Sosyal harcamalar ise liberal devletlerindekinden önemli oranda yüksektir. Gelir transferleri erkek aile reislerinin gelir gereksinimlerini karşılamalıdır. Kadının istihdamı ile kadınlara iş sağlamayı kolaylaştıran sosyal hizmetler mütevazıdır. Gerçekçi olmak gerekirse kadınların hem iş gücüne katılım oranları hem de toplam istihdam düzeyleri düşüktür (Aydın ve Çakmak, 2017; Gökbunar vd., 2008; Myles ve Quadagno, 2002; Esping-Andersen, 1990).

Bu modeli benimseyen ülkeler istihdamı yüksek tutmak yerine; sosyal güvenlik hakkını yani sosyal sorunları, sosyal güvenlik yoluyla giderme yöntemini benimsemişlerdir. Ancak gelir ve çalışma düzeyi ile sosyal güvenlik hakkının ilgili olduğunu unutmamak gerekir (Kuisma, 2007; Ferrera, Hemerijck ve Rhodes, 2000). Devlet bir takım nedenlerle iş veya gelir kaybına uğrayanlara çözüm yolu olarak yeni istihdam olanakları sunmak yerine bu bireylere yönelik korumacı, telafi ve tazmin edici politikalar üretir. Böylece devlet, iş-gücü piyasasından çıkışları güvence altına almayı tercih etmektedir. Oysa bireyleri iş-gücü piyasasında kalmaya ya da oraya girmeye teşvik edici uygulamalar çoğunlukla askıdadır. Ancak burada istihdamla ilgili önemli bir noktanın altını dikkatlice çizmek gerekir. Her ne kadar Kıta Avrupası geleneğini taşıyan ülkeler ile ilgili böyle bir intiba oluşsa da bu ülkelerde son 15 yıldır çalışmaya ve işgücü piyasasına katılımı zorlamak için, sosyal güvenlik sisteminde ciddi liberal reformlar yapıldığını da vurgulamak zorundayız.

Finansal refah olanakları, vergilerden ziyade sosyal sigorta ilkesine dayanmakta ve bu refah rejimlerinde sol partiler sağ partilere oranla görece daha zayıf kalmaktadır. Çünkü sağ partiler kiliseye ya da dini kurumlara yakınlıkları ile bilinirken, onların bu yakınlığı aile ve cinsiyete karşı muhafazakâr tutumlarını belirlemenin yanında sosyal politikaya olan bakış açılarını da etkiler. Dolayısıyla bu modelin herkesçe bilinen özelliği geleneksel aileye verdiği önemdir (Aydın ve Çakmak, 2017; Esping-Andersen, 2002). Muhafazakârlara göre sosyal yaşamdaki en önemli ve temel kurum ailedir. Bu yönüyle en güçlü benzerliği Güney Avrupa ülkeleriyle yaşayan bu modelin aile konusundaki en zayıf halkası Belçika ve Fransa'dır. Gelir 
getiren erkeğe yüksek değer yüklenir, Eş ve annelerin ise piyasanın iş koşullarına katılımı destek görmemektedir ${ }^{4}$. Aile ile birlikte istihdamla ilişkili sosyal sigorta da insanı korur çünkü istihdamın garantisine güçlü bir vurgu yapılır. Ancak bu ülkelerdeki sosyal sigorta, düzensiz iş kariyeri olan işçilere ve kadınlara yeterince sosyal güvenlik sağlamadığı için eleştirilmektedir (Esping-Andersen, 2002; Ferrera vd., 2000; Esping-Andersen, 1994).

Kıta Avrupası refah rejiminde bulunan ülkelerde, refah devletine bakış açılarının çok da olumlu olmadığı düşünülebilir. Bunun ana sebebi refah devletinin toplumu bir arada tutan ve nesiller arası kültürel aktarım sağlayan aileyi günden güne erittiği düşüncesidir. Onlara göre aile yapısında parçalanma ile refah devletinin büyümesi arasında doğru orantı vardır (Özdemir, 2004).

\section{Sosyal Demokrat veya İskandinav Refah Rejimi}

İskandinav refah rejiminin önde gelen temsilcisi İsveç olup diğer ülkeler Finlandiya, Hollanda, Norveç ve Danimarka'dır. Öne çıkan ilkeleri ise sınıflar arasında eşitlik, sosyal dayanışma ve evrenselliktir. Vatandaşa sunulan faydalar, yüksek vergi düzeyi getiren ve refahın temel aktörü durumunda olan devlet tarafından sağlanmaktadır. Özellikle orta sınıf ile çalışanlar için kayda değer yararlar söz konusudur (Koçak, Kavi ve Es, 2017; Pringle, 1998). Gereksinimlerin yüksek düzeyde karşılanması ile oluşacak eşitliği hedefleyen bir refah devleti anlayışı, minimum gereksinimlerin karşılanmasına dayalı bir eşitliği önler. İskandinav refah rejimi, sosyal eşitlikle ekonomik etkinliği en iyi şekilde birleştiren modeldir (Esping-Andersen, 2002).

Sosyal hakların devlet tarafından yoğun olarak sağlandığı, marjinal seviyede ise özel refah düzenlemelerinin, değerlendirmelerinin tutulduğu bir devlet modeli temsil edilir. Kita Avrupası Rejimi'nin aksine, herkese yüksek düzeyde gelir güvencesi sağlama ve gelirin yeniden dağıtımı üzerinde önemle durulur. İskandinav Refah Rejimi'ne giren ülkelerde

${ }^{4}$ Kıta Avrupası Refah Rejimi'nin bu özelliğine istinaden çalışmanın devamında açıklayacağımız Güney Avrupa Refah Rejimi ile de çok az benzer özellik sergilediğini söyleyebiliriz. 
toplam istihdam düzeyi yüksektir çünkü istihdam konusu devletin öncelikli sosyal politikasıdır. Yani refah devletinin sosyal politika uygulama odağı iş-gücü piyasasıdır. İskandinav ülkelerde kamu istihdamı OECD ülkelerinin ortalamalarına oranla iki kat fazladır ancak özel sektör ise istihdam konusunda OECD ortalamalarının biraz altında yer alır. Kadınların iş gücüne katılım oranları yüksektir. Bu nedenle model; istihdam sağlayıcı refah devleti modeli olarak da adlandırılmaktadır (Gökbunar vd., 2008; Myles ve Quadagno, 2002; Stephens, 1996, s.34).

Düşük vasıflı işçiler bile güçlü sendikalar sayesinde görece yüksek ücretler alabilir dolayısıyla sendikal güç daha adil bir şekilde gelir dağılımının gerçekleşmesine katkıda bulunur (Aydın ve Çakmak, 2017; Koçak vd., 2017; Marangoz, 2001). Modelde yer alan ülkeler aileyi güçlendirirken bireyin daha fazla bağımsız olmasını amaçlar. Vatandaşların refah gereksinimlerini mümkün olduğunca piyasadan bağımsız kılmaya yani meta-dışılaştırmaya çalışırlar. Yaşlılık ve diğer refah önlemi gerektiren durumlarda da cömert bir sosyal refah devleti anlayışı ile hareket ederler (Koçak vd., 2017; Özdemir, 2004; Marangoz, 2001). Bu modelin üç karakteristiği; evrensel gelir garantisi, sosyal sigorta ve özellikle çocuk, engelli ve yaşlılara yönelik son derece gelişmiş hizmetlerdir. Bu ülkeler yaşlı ve çocuk yoksulluğunu en aza indirmiş sayılı OECD ülkeleri klasmanında yer alırlar (Özdemir, 2004; Esping- Andersen, 2002; Marangoz, 2001; Esping-Andersen, 1996).

Avrupa' daki diğer ülkelerden farklı olarak bu refah rejiminin başka bir özelliği ise genç ve gençlik merkezli sosyal politika uygulamalarına daha çok emek sarf etmesidir (Esping-Andersen, 1996). Vatandaşlar kendi refah devletlerine yüksek seviyede destek verdiği için bu ülkelerdeki yaklaşımlar daha çok sorun çözme odaklıdır. Yine de son dönemlerde libarizmin etkisiyle İskandinav refah rejimine dahil olan ülkelerin sorun çözme odaklı bakış açılarında duraklamalar olduğu söylenebilir.

\section{Refah Devleti Sınıflandırmasına Yönelik Eleştiriler ve Katkılar}

Esping-Andersen'in üçlü sınıflandırmasına yönelik önemli katkılar olduğu gibi model, farklı yönlerden eleştirilere de açıktır. Eleştirilerin başında sınıflandırmanın farklı rejim türleri arasındaki karmaşıklığı önemsemediği ve refah devleti algısını aşırı basit bir kavrayışa indirgediği 
gelmektedir. Modelde, üçlü sınıflandırmanın yeterli olmadığı açıktır. Daha gerçekçi bir sınıflandırma için daha fazla sayıda rejim türüne gereksinim olduğu vurgulanmaktadır. Örneğin Güney Avrupa Refah Devletleri sınıflandırmaya dâhil edilmemiştir. Model için ülke sınıflandırmalarının doğru biçimde yapılamadığına yönelik fikir ayrılıkları da mevcuttur. Kaldı ki liberal ülkeler arasına İngiltere'nin katılması ve ABD ile İngiltere'nin ayn kategoriye konulması Esping-Andersen'in ciddi biçimde eleştirilmesine neden olmuştur.

İngiltere liberal ülkelerden farklı olarak, vatandaşlarını piyasa şartlarına karşı daha çok korumaktadır. İlaveten, İngiltere İskandinav Modele yakın sayılabilecek bir Ulusal Sağlık Sistemi'ne sahiptir. İngiliz vatandaşlarından her kesim ulusal sağlık sisteminden yararlanmaktadır (Özdemir, 2004). Aynı zamanda kendi sınırları içinde İngiliz Sağlık Sistemi evrensel niteliklidir. Ayrıca Esping Andersen'in sinıflandırması, refah devletlerinin toplumsal cinsiyetle alakalı yönüne pek vurgu yapmadığı ve kadınlara yönelik herhangi bir ayrıştırmayı dikkate almadığ için feministler tarafından eleştirilmiştir (Özalp, 2016; Leibfried ve Obinger, 2003; Marangoz, 2001; Leibfried, 2000). Piyasa göstergelerine sadece belirli gruplar açısından yaklaşmaktadır.

Esping-Andersen'in çalışmaları karşılaştırma temeline dayandığı ve devleti basit bir sosyal güvenlik aygıtı olarak görmekten ziyade, refahın ekonomi politikaları üzerine yansıyan etkilerine odaklandığ 1 için önemlidir. 1990'ların karşılaştırmalı refah devleti çalışmaları, Esping-Andersen'in üçlü sınıflandırmasına yeni ek sistemler öneren çabalar halinde ortaya çıkmıştır (Pringle, 1998; Leibfried, 1993). Bu çabalardan önde gelenleri Leibfried (1993), Castles ve Mitchell (1993) ile Ferrera (1996)'nınkiler olarak belirlenebilir; çünkü hepsinin ortak görüşü refah devletleri sinıflandırmasının üçlü tasnif ile yeterli olamayacağı yönündedir.

Leibfried (1993), Esping Andersen'in sinıflandırması dışında dördüncü bir refah rejiminden bahsederken Castles ve Mitchell ile Ferrera "Güney Avrupa Refah Devletleri'nin" Kıta Avrupası Refah Rejimi başlığı altında ele alınmaması gerektiğini belirtmiştir (Özalp, 2016; Güç, 2015; Ebbinghaus ve Manow, 2004; Ferrera, 1996; Castles ve Mitchell, 1993). EspingAndersen'e katkı olarak görülebilecek diğer sınıflandırmalar; Doğu Avrupa Refah Rejimleri, Asya Refah Rejimleri ve Radikal Refah Rejimleri 
olup Japonya, Avustralya, Asya ve Yeni Zelanda'nın bir kısmını kapsamaktadır. Çalışma konusu itibarıyla bu safhada Güney Avrupa Refah Rejimi'nin özellikleri ele alınacak ve Türkiye'nin modele girişi detaylandırılacaktır.

\section{Güney Avrupa Refah Rejimi ve Türkiye}

Esping-Andersen'in refah rejimi, piyasayı, aile pratiklerini ve sosyal tabakalaşmayı göz önünde bulundurarak refah devletlerini sınıflandırmaktadır. Yani devlet, piyasa ve aile oluşumlarının bileşkesidir. Güney Avrupa Refah Rejimi, Ferrera (1996) tarafından tasarlanmıştır ve Esping-Andersen'in modeline önemli bir katkı olarak düşünülmektedir. Başlangıçta Türkiye Güney Avrupa Refah Rejimi'nde yer almaz, modele sonradan dâhil edilmiştir. Ferrera'nın modelinde ortaya koyduğu özellikler ile Türkiye arasında benzer yönler bulunur. Sharkh ve Gough (2010) bu benzerliklere dikkat çekerek Türkiye'nin Güney Avrupa Refah Rejimi içinde yer alması gerektiğine vurgu yapar.

Sharkh ve Gough (2010)'a göre Türkiye'nin de dahil olduğu bu model, çok parçalı yapıya sahip eşitsiz bir korporatist güvenlik sistemi, bu sistemin dışında kalan geniş bir kendi hesabına çalışanlar ve enformel sektör çalışanlarının varlığına sahiptir. Bu ülkelerde aile dayanışması nüfus artış hızını düşürmektedir. Bunun nedeni; devletin sunduğu çocuk bakım hizmetlerinin, cömert çocuk izinlerinin ve genç çiftlerin yararlanabildiği diğer sosyal destek mekanizmalarının önemli olmaması, genç neslin uzun süre aile yanında yaşamayı ve ev kurmayı geciktirmeyi seçmesidir. Sharkh ve Gough (2010)'un değerlendirmeleri, Buğra ve Keyder (2003)'in araştırması ile benzerlik gösterir. Buğra ve Keyder (2003) Güney Avrupa Refah Rejimi' nin göstergeleri ile Türkiye'nin yeni yoksulluk olgusunu inceleyerek bu refah rejimi içerisinde Türkiye'nin görünümünü berraklaştırmıştır.

Güney Avrupa Refah Rejimi'nde Yunanistan, İspanya, Portekiz, Türkiye, İtalya ve İrlanda Cumhuriyeti yer alır. Tam Oluşmamış Model, bu modelin diğer ismidir. Güney Avrupa Refah Rejimi'nin başlıca özellikleri arasında bireylere sunulan sosyal olanakların ve hizmet eden kurumsal yapıların çok yetersiz olması gelir. Ancak bu modelin uygulandığı ülkelerin yasa ve anayasalarına bakıldığında, modern refah devletinin bütün 
kurumsal gelişmelerinin vaat edildiği görülmektedir. Dolayısıyla bu ülkeler politik vaatler devleti tanımlaması ile ün salan gerçek anlamda da bir refah devleti olmaktan çok uzakta duran devletlerdir (Güç, 2015, s.30; Özdemir, 2004, s.114; Koray, 2003, s.72).

Güney Avrupa Refah Rejimi yüksek ve düşük emekli maaşlarının bir arada olması gibi son derece parçalı ve çarpık gelir koruma sistemlerine sahiptir. Dahası ulusal sağlık sistemleri ve hizmet sunumu gelişmemiş devlet kuruluşları vasıtasıyla tedarik edilir (Aydın ve Çakmak, 2017; Gökbunar vd., 2008; Özdemir, 2004). Bireylerin yoksullukla mücadelesi ise kurumlara, dini oluşumlara ve Katolik Kilisesi'nin sosyal desteğine, çoğunlukla da geleneksel aileye dayanmaktadır (Özdemir, 2004; Buğra ve Keyder, 2003).

Güney Avrupa Refah Rejimi'nin bir kısmında seçim sandığına endeksli parti politikalarını, çok fazla politik vaadi ve düşük bir devlet kapasitesini bir arada bulmak mümkündür. Her an mali krizlerin tetiklenebileceğine dair beklentiler vardır. Ekonomileri dışardan müdahalelere açıktır. Sıklikla ekonomik krizleri tecrübe ederler ${ }^{5}$. Kamunun partizan uygulamalara ve söylemlere son derece açık olması bu refah rejiminde yine görülen özellikler arasındadır. Partizan eylem ve söylemler sonucunda özellikle sosyal yardım uygulamalarında reformların, girişimlerin ve yeniliklerin zayıflığ 1 göze çarpar (Aydın ve Çakmak, 2017; Güç, 2015; Özdemir, 2004; Çağlar ve Keyder, 2003; Pierson, 1998.)

Güney Avrupa Refah Rejimi'nde meslek gruplarının bazıları için cömertliğin pik yaptığı noktaya ulaşmış sosyal transfer sistemleri, bazı meslek gruplarına yönelikte tahmin edilemeyecek ölçüde büyük koruma boşlukları söz konusu olmuştur. Sosyal güvenlik yani sosyal koruma, sosyal fayda ve sosyal fırsatlar açısından içerde olanlar ile dışarda kalanlar arasında keskin bir ayrım bulunur. Eşitsizlik üzerine kurulan, sunulan, dağıtılan kamu hizmetleri çoğu zaman nitelik yönünden yetersiz bulunmaktadır. Diğer taraftan ekonomide kayıt dışı algısı geniştir ve bu algı eşitlik ile ciddi nitelik sorunları doğurmaktadır. Enformel istihdam ile beraber

\footnotetext{
${ }^{5}$ Nitekim son yıllarda küresel ekonomik kriz yaşayan ülkeler arasında Güney Avrupa Refah Rejimi'ne tabi olan ispanya ve Yunanistan'ın bulunması şaşırtıcı değildir. Italya'nın bütçe politikalarının Avrupa Birliği ile sürekli uyuşmaması, Avrupa Birliği'nin ilgili birimlerinde italyan ekonomisi üzerine sık tartışmaların yaşanması ve Türkiye'nin ekonomik yapısındaki dalgalanmalar da Güney Avrupa Refah Rejimi'ne dair önemli göstergeler olabilir.
} 
gerek işçi çalıştırma da gerek üretim ve pazar alışverişlerinde kayıtdışı işlemlerin büyüklüğü söz konusudur (Sharkh ve Gough, 2010; Gökbunar vd., 2008; Çağlar ve Keyder, 2003; Ferrera vd., 2000).

Güney Avrupa Refah Rejimi'nin kayda değer bir kısmında demografik yapı gittikçe kötüleşmektedir. Özelikle dünyada İspanya ve İtalya en hızlı yaşlanan ülkelerin başını çekmektedir. Hızla yaşlanmaya rağmen küçük işletmelerin sağladığı istihdam yapısı içerisinde kendi hesabına veya ücretsiz aile işçisi olarak çalışanların çok önemli olduğu bir emek piyasası da bulunur. Yine emek piyasası bağlamında, dış ülkelere işçi göçünün ve yabancı ülkelerde çalışan işçilerin kazançlarının bir kısmını ülkede kalan aile fertlerine gönderebilmesi büyük önem taşır (Özdemir, 2004; Çağlar ve Keyder, 2003; Ferrera vd., 2000).

Güney Avrupa Refah Rejimi'nde sosyal güvenlik sistemi korporatist özellikler gösterir ve evrensel sağlık sigortası uygulaması da yerleşmemiştir ${ }^{6}$. Devletin sosyal güvenlik alanında formel kanallar vasıtasıyla oynadığı rolün sınırlı kalması, buna karşılık devletin tikelci, içinde patronaj ilişkilerinin önemli rol oynadığı mekanizmalarla bireyin geçim olanaklarını önemli ölçüde etkilemesi söz konusudur (Aydın ve Çakmak, 2017; Güç, 2015; Çağlar ve Keyder, 2003).

Nihayetinde sosyal politika uygulamalarına dair söylenebilecek son söz istihdamla bağlantısı olmayan sosyal yardım kalemlerinin yok denecek kadar az olması, yani direkt yoksulluk ve yoksulluktan kaynaklanan sosyal dışlanmayı önlemeye yönelik çalışmaların bulunmaması dikkat çekicidir (Çağlar ve Keyder, 2003). Bilhassa yoksulluktan kaynaklanan sosyal dişlanma önlenemez iken kamunun sunduğu belirli hizmetlerin dağ1tım ve planlama aşamalarında riyakârlık, yolsuzluk ve tikelcilik yoğun olarak görülebilmektedir. Çıkar alışverişini politik arena ve desteğe yansitan partilerin varlığı da hissedilmektedir.

\footnotetext{
${ }^{6}$ Türkiye için vergi ile finanse edilme prensibine dayalı olmak yerine kesinti ile oluşturulan, kamu ve özel hizmetlerin karışımını içeren bu ortaklığın bir çıktısı olarak tam gün yasası, aile hekimliği uygulaması, kampüs ve şehir hastanelerinin kurulmaya başlanması ve Genel Sağlık Sigortası'na geçilmesi ile Sağlıkta Dönüşüm Programı somut bir örnektir. Özellikle Sağlıkta Dönüşüm Programı'nın uzun yıllar adım adım devam edebileceği de düşünülmektedir. Öte yandan sağlıkla ilgili uygulamaların günümüz itibari ile Türkiye'de daha çabuk kabul gördüğü, daha çok önemsendiği ve takip edildiği de söylenebilir.
} 


\section{Türkiye'nin Refah Devleti ve Makro Sosyal Hizmet Uygulamaları Üzerine Çıkarımlar}

Sosyal hizmet mesleği, sosyal refah alanı içerisinde gelişmiş bir meslek ve disiplindir. Mesleğin en önemli özelliklerinden biri, kaynaklar ile müracaatçı sistemlerini bağlantılandırmaktır. Var olan kaynaklar ise genellikle kamusal nitelik taşımaktadır (Şahin, 2000, s.6). Sosyal hizmet mesleği için her bir vatandaş, güçsüz ya da dışlanmış bir grup adına makro boyutta potansiyel yapıcı bir güçlendirme aracıdır (Adams, 2002, s.29). Bu anlamda sosyal hizmetler, vatandaşın sosyal işlevsellikle ilgili sorun ve ihtiyaçlarına yönelen genellikle kamusal nitelikli hizmetler olup sosyal refah politikaları ile makro düzeyde ele alınabilir.

Abramovitz (1998), mesleğin birey ve toplum arasındaki konumunun sıklıkla uygulayıcıları, insanları ve programları sorunların çözümü için dengede tutma ile refah politikalarına meydan okuma arasında bıraktığını açıklar. Örneğin sosyal hizmet; bir yandan müracaatçıları adına savunuculuk yaparken bir yandan onların çıarları için lobicilik faaliyetleri yürütebilir. Benzer bir örnek, sosyal hizmetin toplum örgütlenmesi ile ilgilenirken politika yapıcılığı göz ardı etmemesi, işlevsiz kurum politikalarına takılı kalmaması ile ilgili de verilebilir (Zengin ve Çalış, 2017). Lorenz (2005), insana ve topluma yardım etme hedefinde olan sosyal hizmet uzmanlarının mesleki yardım sürecinde toplumsal kaynakları kullanarak refah politikalarına etki etmeye çalıştığını ve kamusal yaşamın sosyal boyutundan haliyle sosyal sorunlardan sorumlu olduklarını açıklar.

Türkiye'nin refah rejimi ve sosyal hizmet örgütlenmesi sosyal sorunların önlenmesinde koruyucu-önleyici politikalar gütmemekte daha çok tedavi ve rehabilite edici bir özellik sergilemektedir. Sosyal sorunlar ortaya çıtıktan sonra sosyal hizmet müdahaleleri devreye girmektedir. Dolay1sıyla bu yaklaşım sorunları kronik hale getirerek, sorunların çözümünü güçleştirmektedir. Son dönemde Aile Sosyal Destek Programı (ASDEP) vb. projeler vasıtası ile sosyal hizmet alanında koruyucu-önleyici uygulamalar önemsenmeye başlamıştır. Ancak uygulamaların detayına bakıld1ğında, mantığı itibarıyla Güney Avrupa refah rejiminin izleri görülmektedir. 
ASDEP uygulaması sosyal hizmet açısından risk altında bulunun ailelerin taramasını içerir. Bu amaçla "sosyal çalışma görevlileri" bulunduğu illerde, Aile, Çalışma ve Sosyal Hizmetler İl Müdürlüklerine bağlı ilçe bazlı Sosyal Hizmet Merkezleri bünyesinde alan taramasına çıkar. Sosyal Hizmet Merkezi'ne bağlı olarak hareket edip alan taramasına çıkan profesyoneller sosyal çalışma görevlileri adı altında toplanırsa uygulama ehline verilmemiş olur. Alan taramasını kanunla sosyal çalışma görevlisi tanımina uydurulan profesyoneller yapmaktadır ve bu profesyonellerin kayda değer ölçüde az bir kısmı sosyal hizmet uzmanıdır. Oysa alan taramasının yoğunlukla sosyal hizmet uzmanlarının eliyle makro müdahale odağı göz önünde bulundurularak yapılması doğru bir seçim olacaktır.

Benzer durum sosyal yardımların dağıtımında ve sosyal inceleme raporlarının (SİR) düzenlenmesinde görülmektedir. Sosyal hizmet uzmanı yerine sosyal çalışma görevlileri burada da tercih edilmektedir. Kanunlarımız hak temelli olsa da kamunun yaklaşımı hayırseverlik ilkesi üzerinden yürüdüğü için SİR'lerin düzenlenmesi konusu sadece sosyal hizmet mesleğinin eğitimini alanlara teslim edilmemektedir. SİR'lerin sosyal hizmet müdahale sürecinde sosyal hizmet uzmanları tarafından mesleki yetkinlikleri çerçevesinde oluşturulan formlar olduğu, mesleki uygulamaları resmiyete döktüğü sıklıkla göz ardı edilmektedir (Çifci ve Ocaklı, 2015). Hayırsever eğilimin hüküm sürmesi beraberinde sosyal hizmet işlevini herkes yerine getirebilir algısını doğurmaktadır.

Özellikle sosyal yardım programlarının istihdamla bağlantısının bulunmaması kamunun hayırsever bakışını daha da güçlendirmektedir. Türkiye'de sosyal yardımlar işsizliği engellemez (Tekindal, 2018; Buz ve Aygüler, 2017). Smith (2000), işsizliğin daha fazla işsizliği beslediğini, uzun süreli işsizlerin iş-gücü piyasasına yeniden kavuşma yeteneklerini yitirdiklerini vurgular. Yüksek işsizliğin kısır döngüsü sosyal güvenlik bütçesinde de artışlara neden olmaktadır. Dolayısıyla hayırseverlik algısı üzerinden mesleklerin itibarsızlaştırılması, birbirlerinin yerine ikame edilmesi tipik patronaj ilişkilerini sosyal hizmet alanında gözler önüne sererken ne yoksulluğa ne de işsizliğe yönelik kalıcı çözümler sunulmaktadır. Sosyal hizmet sunumu bu yönüyle Güney Avrupa refah rejimi özelliğini taşımaktadır.

Türkiye'deki sosyal hizmet sunumunda söz konusu patronaj ilişkilerini destekleyen başka göstergeler de mevcuttur. Türkiye'de Aile, Çalışma 
ve Sosyal Hizmetler Bakanlığı bulunmasına rağmen bakanlığın üst yönetim kademelerinde sosyal hizmet uzmanlarından yeterince istifade edilmemesi önemli bir eksikliktir. Paralel biçimde bakanlığın uzman ya da uzman yardımcısı kadrosunda sosyal hizmet uzmanlarının görece az olması; iktisat, işletme, hukuk, kamu yönetimi vb. lisans mezunlarının bu kadrolarda daha çok değerlendirilmesi sosyal hizmet uzmanlarını kendi hareket alanlarında, ait oldukları ortamlarda ötekileştirmektedir.

Refah devletinde sosyal refah kavramı ile en çok özdeşleştirilen profesyoneller sosyal hizmet uzmanlarıdır (Şahin, 2000, s.13). Sosyal hizmet uzmanlarının kendi bakanlıklarının temel direği olmalarına rağmen yeterince değer görmemesi patronaj ilişkilerine başka bir kanıttır. Dahası sosyal hizmet sunumunun merkezi yapısının yerelle bütünleşememesi ve sunumun taşra yapılanmasının idaresinin de genellikle sosyal hizmet mesleğinin ilke ve felsefesine uzak alanlardan yöneticiler ile sürdürülmesi neden Güney Avrupa refah rejimine sıkı sıkıya bağlı olduğumuzu gösterir niteliktedir. Bu durum nedeniyle kamu kurumlarının partizan dayatmalara ve yönlendirmelere açık olduğu kamuoyu tarafından hissedilmektedir. Kamu kurumlarının partizan dayatmalara ve yönlendirmelere açık olması aslında makro sosyal hizmet uygulamalarının sunumuna ve vatandaşın etkili hizmet almasına ket vurmaktadır.

Türkiye'de sunum itibarıla sosyal yardımların damgalamaya açık, evrensel olmaktan çok uzak ve yetersiz, daha çok hibe ve ayni şekle odaklandığını ve sosyal haklar çerçevesinde düzenlenmediğini görmekteyiz (Dedeoğlu, 2009). Nedeni ise sosyal yardım kriterlerinin yoksulluk temelinde ele alınmasıdır (Smith, 2000). Türkiye'de sosyal yardımlar ile ilgili yapılan bir analizde, sosyal yardımların hangi gruplara ve hangi amaçla verildiği sorusu ön plana çıkmaktadır (Tekindal, 2018). Sosyal yardımlar bireylerin toplum içindeki statüsünü belirler ve hizmet alanların sosyal yardımlar vasıtası ile yaşam kalitesini yükseltmek temel hedeftir.

Bu kapsamda her anlamda firsat eşitliğinin sağlanması ön planda olmalıdır. Sosyal yardım adı altında yardım alan aktörlerin rol ve statülerinde bu yardımlarla birlikte nasıl bir değişim yaşandığı niteliksel olarak incelenmelidir. Türkiye'de verilen sosyal yardımlar bireyin muhtaçlık döngüsünün devamını sağlamakta ve yoksulluğu kronikleştirmektedir (Tekindal, 2018; Buz ve Aygüler, 2017). Yoksul kişinin yaşamını bir bütün olarak kavrayan ve onu kendi ayakları üstünde durabilen bir birey haline 
getirmeyi amaçlayan bir yaklaşım henüz söz konusu değildir. Ülkenin mevcut sosyal yardım yaklaşımı bireyi yoksullukla ilişkili diğer sosyal sorunlara karşı savunmasız bırakmaktadır.

Şiddet vakalarının bir yönünün yoksullukla ilişkili olduğu, yoksulluğun baskı ve şiddet davranışını ortaya çıardığı bilinir (Güler, Tel ve Tuncay, 2005; Kardam ve Yüksel, 2004; Özdek, 2002). Birey kendi ayakları üzerinde duramadığı vakit yoksullukla mücadele edebilmek adına maruz kaldığ şiddeti tolare edebilmektedir (Altay, 2007; Güler vd., 2005; Kardam ve Yüksel, 2004). Kadınlar bu çaresizliği erkeklere oranla daha yoğun tecrübe eder ve kadınlar erkeklere göre daha yoksuldur (Buz ve Aygüler, 2017; Şener, 2012; Şener, 2009). Devletin rolü ise düzenleyici, korumacı bir yaklaşım olarak ifade edilebilir. Kadınların sosyal hakları ise bizce geliştirilmeye açıtır. Bu noktada sosyal adaletin ve demokrasi kültürünün makro sosyal hizmet uygulamaları ile geliştirilememesi doğaldır. Bilhassa sosyal adalet üst okumasını aile ve kadın kavramları üzerinden tartışmakta yarar vardır.

Türkiye'de aileye verilen değer son derece üst düzeydedir. Adında aileye vurgu yapan bir bakanlık teşkilatı bulunmaktadır. Böylelikle aile kavramının bakanlık düzeyinde açıktan belirtilmesi kapalı aile politikalarından açık aile politikalarına geçmemizi kolaylaştırmıştır. Güney Avrupa refah rejiminin aile pratiklerini önemsediğini düşündüğümüzde Türkiye'de yaşanan bu değişim şaşırtıcı olmayacaktır. Aynı zamanda bu yönümüzle muhafazakâr refah devletlerini de andırmaktayız.

Türkiye'de aile kavramı o kadar önemsenmektedir ki kadının anne olmasını kolaylaştıran düzenlemeler bir çırpıda teşvik odaklı hale gelmiştir. Yarım gün mesai, süt izinleri, aile ve çocuk yardımları her ne kadar kadının anne rolünü desteklese de aynı zamanda kadını iş-gücü piyasasından uzaklaştırabilecek riskli uygulamalardır. Soyseçkin (2015) hükümetlerin son yıllarda kadınların istihdamının arttırılmasını önemli bir politik hedef olarak gündeme getirdiğini belirtmektedir. Ancak hükümetler, kadınların istihdama katılımının önündeki en büyük engellerden olan bakım sorumluluğunu çözmek yerine, esneklik adı altında yarı-zamanlı çalışmayı norm haline getirme çabası içindedir. Yani kadınların hem çalışması hem de hane içindeki tüm bakımı üstlenmeleri beklenmektedir. Böylelikle kadın istihdamında yalnızca sayısal bir artışın yakalanması hedeflenirken, 
işlerin niteliği ve getirileri ikinci plana atılmaktadır. Ayrıca, cinsiyetçi işbölümü de pekiştirilmiş olmaktadır (Soyseçkin, 2015). Tam da bu noktada sosyal adaletin kadınlardan yana işlemediğini anlamak zor değildir.

İskandinav ülkelerinde ve Avrupa'nın önemli bir kısmında benzer yardımlar bulunurken bu yardımlar; gayri resmi bakım anlayışının yaygınlaştırılması, ekonomik destek, yıpranma payları, her mahalleye bir okul öncesi eğitim kurumu gibi uygulamalarla birlikte sunularak kadının bakım sorumluluğunu azaltır ve kadını iş-gücü piyasası içinde konumlandırır (Pfau-Effinger, 2005; Misra ve Akins, 1998; Hernes, 1988). Kaldı ki açık aile politikasına geçişle birlikte Türkiye'de önceden genel müdürlük seviyesinde temsil edilip doğrudan başbakanlığa bağlı olan kadınlar (Kadının Statüsü Genel Müdürlüğü) artık Aile, Çalışma ve Sosyal Hizmetler Bakanlığı'nın içinde konumlandırılarak bakanlık çatısı altında temsil edilmektedir.

Türkiye'de bakım konusunun mağdurları sadece kadınlar değildir. Türkiye'de temel olarak liberal ekonomi kuralları benimsenir iken yaşl1lar, engelliler ve kronik hastalar gibi kimi hassas grupların bakımı devlet teşviki ile ilerlemektedir. Devlet teşviki bakıma odaklı olduğundan hizmet alanların üretim mekanizmalarına katılmasına yönelik bir sosyal politika ya da program henüz ülkemizde bulunmamaktadır.

Sosyal güvenlik sistemi, genel sağlık sigortasının bulunması, sağlık hizmetlerinin dönüşmesi Anglo-Sankson modeldeki ulusal güvenlik politikalarına benzemektedir. Türk sosyal güvenlik ve sosyal hizmet sistemlerinin ise sosyal adaleti ne ölçüde temsil ettiğini gösteren bilimsel çalışmalar henüz finansman sorunları, yasal prosedürler ve kurumlarla çalışma izinleri konusunda çıkan engeller gibi nedenlerle yapılamamaktadır. Diğer taraftan çocuk ve yaşlı yoksulluğuna, genç işsizliğine, çocuklara, gençlere ve yaşlılara yönelik sosyal politikalar ülkemizde mevcut olmakla birlikte bu politikaların niteliği tartışma konusudur. Çocuk, genç ve yaşlılara yönelik verilen sosyal hizmetlerin niteliğini değerlendiren çalışmalar (Tuncay ve Yıldırım, 2015; Danış, 2009; Erbay, 2008; İkizoğlu, Önal Dölek ve Gökçearslan Çifçi, 2007; Dönümcü, 2006; Kurt, 2006; Danış, 2005; Karataş, 1996) yok denecek kadar azdır.

Türkiye'de ilginç olan başlıca konu yasal düzenlemelerde sosyal hizmetlerin işlevi belirtilirken hizmet sunumunun parçalı bir yapı gösterme- 
sidir. Sosyal hizmetler; Sivil Toplum Örgütleri, Yerel Yönetimler, Özel Teşebbüsler, Sağlık Bakanlığı, Adalet Bakanlığı ve Aile, Çalışma ve Sosyal Hizmetler Bakanlığı'nın eliyle yürütülmektedir. Farklı kaynaklardan hizmet sunumu sosyal hizmet uzmanlarının makro uygulama standartlarına sahip olmasinı engellemektedir.

Kaldı ki bazı dönemlerde kamu hiyerarşisinde çok başlılık da görülmektedir. Mesela sosyal hizmet merkezleri ilk açıldığında il müdürü sosyal hizmet merkezi müdürü mü olacak? Sosyal hizmet merkezi müdürü il müdürü olmayacak ise merkez müdürü kim olacak? Kime bağlı olacak ya da özerk mi olacak? İl müdürlügü mü sosyal hizmet merkezini denetleyecek? Yoksa sosyal hizmet merkezleri Ankara tarafından mi denetlenecek? gibi durumlar alanda fazlasıyla tartışmaya açıktı. Sosyal hizmet alanında her yeni dönüşüm aslında beraberinde krizi getiriyordu.

Öte yandan özellikle Anayasa'da sosyal haklar açıkça koruma altına alınmıştır. Bununla birlikte Türkiye'de sosyal hakların karşılığı olan hizmetler uygulamaya istenilen ölçütlerde aktarılamamıştır (Dedeoğlu, 2009). Kurumsal yapı ve vatandaşa devlet eliyle sunulan hizmetlerin yetersiz olduğu düşünüldüğünde Türkiye'nin sosyal hizmet politikalarının vaatler odağında seyrettiği söylenebilir. Gerçekte sosyal refah ve sosyal hizmet politikası sosyal sorunları çözmeye yönelen bir politikadır (Abramovitz, 1998). Sosyal hizmetin makro bakış açısı ile ifade edilen tüm bu koşullar esasta sosyal hizmet uzmanlarının gerçekleştireceği mesleki müdahaleleri çevreleyen temel koşullar olup müdahalenin niteliğini doğrudan etkilemektedir.

\section{Sonuç Yerine}

Sosyal hizmet eğitimi ve mesleği; insan yığınlarının sorunları, toplumsal koşullar ve sosyal politikalarla yakından ilişkilidir. Ancak sosyal politika alanında kendimizi yeteri kadar yenileyemediğimiz ve tıkandığımız bazı noktalar mevcuttur. Demokrasi ve sosyal adalet çerçevesinde kaynakların iyileştirilmesi ya da artırılması, piyasa koşullarının sürekli düzenlenmesi gerekmektedir. Bu nedenle sosyal hizmet uzmanlarının sosyal politika kulvarına katılımı, işbirliği önemlidir. Makro düzeyde çalışma çevre, topluluk ve toplumda değişme ve gelişme yaratmayı hedeflediği için sosyal politikalardan ayrı düşünülmemelidir. 
Toplumla sosyal hizmetin politik savunuculuğu ve sosyal politika ile olan ilişkisi; demokratik toplum düzenini oluşturmak, kapsayıcı, destekleyici, ırkçı ya da cinsiyetçi olmayan politikalar ve kurumlar yaratmak olarak sıralanabilir. Bu noktada refah devletinde sosyal adaleti gerçekleştirebilecek örgütlenme çabaları da sosyal hizmet uzmanlarının önderliğinde başarıya ulaşabilir. O zaman refah devletinde sosyal hizmet uzmanlarının rol ve sorumluluklarının gözden geçirilmesi iyi bir başlangiç olabilir. Refah devletinde sosyal hizmet uzmanına yönelik kapsamlı bir algı oluşturmak adına başka pek çok çalışma konusu da gündeme gelmelidir.

"Refah devletinde makro düzeyde sosyal hizmet uzmanı nasıl çalışmalıdır?", "Güney Avrupa refah rejimine göre sosyal hizmet uzmanları hangi temel göstergeleri göz önünde bulunduran politika süreçlerine katılmalıdır?", “Güney Avrupa Refah Rejimi'nde yer alan ülkelerdeki sosyal hizmet uzmanlarının alan deneyimleri ve çalışma koşulları nelerdir?", “Sosyal hizmet uygulamaları Güney Avrupa Modeline kıyasla Liberal-Muhafazakâr-İskandinav modellerde neden daha işlevseldir?", "Refah Rejimleri ile sosyal hizmet mesleğinin uygulanabilirliği, toplumsal kabulü ve itibarı açısından ne tür ilişkiler mevcuttur?" gibi soruların yanıtlarını sosyal hizmet camiasının araması gerekmektedir.

Bu çalışmanın Esping-Andersen'in refah devletleri sınıflandırmasına yönelik bir hatırlatma mantığı ile hareket etmesi, sosyal hizmet profesyonelleri ve akademisyenlerinde farkındalık yaratabilir. Bu nedenle ilerleyen y1llarda sosyal hizmet alaninda refah devleti ve sosyal politika konuları ile ilgili kapsamlı çalışmaların yapılacağı düşünülmektedir. Neyse ki Türkiye'de az sayıda da olsa sosyal hizmetin makro boyutuna kafa yoran, sosyal politika tarafında duran sosyal hizmet profesyonelleri ve akademisyenlerinin var olması umut vericidir. 
EXTENDED ABSTRACT

\title{
Esping-Andersen's Welfare State Classification and Turkey's Position of Based on Macro Social Work Practices
}

\author{
* \\ Buğra Yıldırım - Fatih Şahin \\ Manisa Celal Bayar University
}

Policies regarding the social problems of individuals in the social environment, collective regulations for the change and development of society are macro social work practices. Macro social work practices are interpreted in different forms within each country's specific sociopolitical and cultural dynamics. In order for social workers to implement macro practices, they must have social policy knowledge. In this context, it would not be the right choice to take action without knowing which welfare regime Turkey falls within and without understanding the similar countries and the common characteristics. Moreover, as human needs increase and diversify, the desire to embrace the welfare state will also increase. The term welfare state, on the one hand, stands for strong and wealthy countries, and on the other hand, refers to states that offer social rights and social policies to its citizens at a high level. Nowadays, the most accepted, criticized and referenced source by the scientific circles is Esping-Andersen's welfare state classification. Esping-Andersen classified the social stratification in terms of the common characteristics of welfare states by taking market and family practices as a basis. In this respect, the study aims to summarize Esping-Andersen's welfare state classification in general terms. On the other hand, the desire to explain Turkey's position among the welfare states in terms of macro social work practices is the main concern of this study.

The distinction in the classification of Esping-Andersen's tripartite welfare regime lies in the common characteristics of the states. States with common characteristics and similar social policy approach are included in the same welfare regime. There are important contributions of the triple 
classification of Esping-Andersen while the model is also open to criticism. One of criticisms is that the classification misses the complexity between the different regime types and it reduces the perception of welfare state to an extremely simple understanding. In the model, it is clear that triple classification is not sufficient. It is emphasized that more types of regimes are needed for a more realistic classification. Nevertheless, the work of Esping-Andersen is important because it is based on comparison and focuses on the effects of welfare on the economic policies of the state, rather than as a simple social security apparatus.

On the other side, the social work profession is an advanced profession and discipline within the social welfare field. One of the most important features of the profession is to link resources with the client systems. The existing resources are generally public. For the social work profession, each citizen is a potential constructive empowerment tool in the macro level on behalf of a weak or marginalized group. In this sense, social services are generally public services oriented towards the problems and needs of the citizens regarding social functionality and can be discussed at the macro level with social welfare policies. For example, social work can, on the one hand, conduct lobbying activities for their clients' interests while advocating on behalf of them. A similar example can be given as, social work does not ignore policy-making when dealing with community organization, and not to be stuck in dysfunctional corporate policies.

Turkey's welfare regime and social work organization are not intended protective-preventive policies for the prevention of social problems. It shows more treatment and rehabilitating features. After the emergence of social problems, social work interventions are involved. Therefore, this approach makes the problems chronic and makes the solution of the problems difficult. Social work education and profession is closely related to the problems of human masses, social conditions and social policies. However, there are some points in the social policy area that we cannot sufficiently renew our self and come to a deadlock. In the framework of democracy and social justice, resources need to be improved or increased, and market conditions need to be regulated continuously. For this reason, it is important for social workers to participate in social policy. 
Working at macro level; it should not be considered separate from social policies as it aims to create change and development in the environment, community and society. Political advocacy of social work with society and its relationship with social policy can be listed as; creating a democratic society, creating an inclusive, supportive, non-racist or non-sexist policies and institutions. At this point, the organization efforts that can realize social justice in the welfare state can also be successful under the leadership of social workers. Then it may be a good start to review the roles and responsibilities of social workers in the welfare state. In the following years, it is thought that comprehensive studies will be carried out on the welfare state and social policy in the social work field. In this study, it is aimed to scale university students' leisure time activities.

\section{Kaynakça / References}

Abramovitz, M. (1998). Social work and social reform: An arena of struggle. Social Work, 43(6), 512-526.

Adams, R. (2002). Social policy for social work (First published). New York: Palgrave Macmillan.

Alcock, P. ve May, M. (2014). Social policy in Britain (Fourth Edition). Basingstoke: Palgrave Macmillan.

Altay, A. (2007). Bir kamu mali olarak sosyal sermaye ve yoksulluk ilişkisi. Ege Akademik Bakış Dergisi, 7(1), 337-362.

Aslan, H. (2017). Sosyal refah devleti modelleri üzerine bir inceleme: Türkiye analizi. İçinde: T. E. Gençer ve İ. C1lga (Eds.). Sosyal Hizmeti Yeniden Düşünmek: Sosyal Çalışma Üzerine Eleştirel Tartışmalar (1. baskı, ss. 255-241). Ankara: Nika Yayınevi.

Austin, M. J., Coombs, M. ve Barr, B. (2005). Community-centered clinical practice: Is the integration of micro and macro social work practice possible?. Journal of Community Practice, 13(4), 9-30.

Aydın, M. K. ve Çakmak, E. E. (2017). Sosyal devletin temelleri. Bilgi Sosyal Bilimler Dergisi, 34(1), 11-19. 
Buğra, A. ve Keyder, Ç. (2003). Yeni yoksulluk ve Türkiye'nin değişen refah rejimi. (BM Kalkınma Programı Proje Raporu), 30 Ekim 2018 tarihinde http://www.tr.undp.org/content/dam/turkey/docs/povreddoc/UNDP-TR-new_poverty.pdf web adresinden erişildi.

Buz, S. ve Aygüler, E. (2017). Amartya Sen'in kapasite-yapabilirlik yaklaşımı bağlamında Türkiye'de yoksulluk durumu. Javstudies: International Journal of Academic Value Studies, 3(15), 177-189.

Castles, F. G. ve Mitchell, D. (1993). Wolds of welfare and families of nations. İçinde: Francis G. Castles (Ed.). Families of Nations: Patterns of Public Policy in Western Democracies (First ed., ss. 93-128). Andershot: Dartmounth.

Cifci, E. G. ve Ocaklı, B. Ö. (2015). Sosyal hizmet uzmanları neden sosyal inceleme raporlarını yazarlar?. Sosyal Hizmet, Ocak-Haziran / Temmuz-Aralik, 37-40.

Danış, M. Z. (2005). Yaşama derinden bir kucak. Ankara: Türk Geriatri Vakfı Yayınları.

Danış, M. Z. (2009). Türkiye'de yaşlı nüfusun yalnızlık ve yoksulluk durumları ve sosyal hizmet uygulamaları açısından bazı çıkarımlar. Toplum ve Sosyal Hizmet, 20(1), 67-83.

Dedeoğlu, S. (2009). Eşitlik mi ayrımcılık mı? Türkiye'de sosyal devlet, cinsiyet eşitliği politikaları ve kadın istihdamı. Çalışma ve Toplum, 2(21), 41-54.

Demirbilek, S. (2009). Sosyal politika bağlamında sosyal hizmet. (Birinci basım), İzmir: Dokuz Eylül Üniversitesi İktisadi ve İdari Bilimler Yayınları.

Dönümcü, Ş. (2006). Yaşlı ve sosyal hizmetler. Turkish Journal of Physical Medicine and Rehabilitation, 52 (Özel Ek A), A42-A46.

Ebbinghaus, B. ve Manow, P. (2004). Introduction: studying varieties of welfare capitalism. İçinde: $B$. Ebbinghaus ve $P$. Manow (Eds.). Comparing Welfare Capitalism (First ed., ss. 1-22). London: Routledge.

Erbay, E. (2008). Çocuk işçi olmak: Çocuk işçiliğine retrospektif bir bakış. Ankara: Sosyal Hizmet Uzmanları Derneği Genel Merkezi.

Esping-Andersen, G. (1990). The three worlds of welfare capitalism. Cambridge: Polity Press. 
Esping-Andersen, G. (1994). After the golden age: The future of the welfare state in the new global order. 27 Ekim 2018 tarihinde https://www.econstor.eu/bitstream/10419/148839/1/863129331.pdf web adresinden erişildi.

Esping-Andersen, G. (1996). After the golden age? Welfare state dilemmas in a global economy. İçinde: G. Esping-Andersen (Ed.). Welfare State in Transition: National Adaptations in Global Economics (First published, ss. 1-31). London: Sage Publications.

Esping-Andersen, G. (2002). Towards the good society, once again? İçinde: G. Esping-Andersen (Ed.). Why We Need A New Welfare State? (First published, 1-25). New York: Oxford University Press.

Ferrera, M. (1996). The Southern model of welfare in social Europe. Journal of European Social Policy, 6(1), 17-37.

Ferrera, M., Hemerijck, A. ve Rhodes, M. (2000). Recasting European welfare states for the 21st century. European Review, 8(3), 427-446.

Güç, Y. (2015). Refah devletinin gelişimi ve Türkiye'de refah devleti algısı: İstanbul ilinde bir alan araştırması. Doktora tezi, İstanbul Üniversitesi, İstanbul.

Gökbunar, R., Özdemir, H. ve Uğur, A. (2008). Küreselleşme kıskacındaki refah devletinde sosyal refah harcamaları. Doğuş Üniversitesi Dergisi, 9(2), 158-173.

Güler, N., Tel, H. ve Tuncay, F. Ö. (2005). Kadının aile içinde yaşanan şiddete bakışı. CÜ Tıp Fakültesi Dergisi, 27(2), 51-56.

Hernes, H. M. (1988). The welfare state citizenship of Scandinavian women. İçinde: K. B. Jones ve A. G. Jonasdottir (Eds.). The Political Interests of Gender: Developing Theory And Research With A Feminist Face (First ed., ss. 187-213). London: SAGE.

İkizoğlu, M., Önal Dölek, B. ve Gökçearslan Çifçi, E. (2007). Çalışan çocukların sorunları ve geleceğe ilişkin beklentileri. Toplum ve Sosyal Hizmet, 18(2), 21-36.

Kardam, F. ve Yüksel, İ. (2004). Kadınların yoksulluğu yaşama biçimleri: Yapabilirlik ve yapabilirlikten yoksunluk. Nüfusbilim Dergisi, 26(1), 45-72.

Karataş, K. (1996). Genç işsizliği: ekonomik toplumsal ve ruhsal sonuçları. Ankara: Sosyal Hizmet Uzmanları Derneği Genel Merkezi. 
Keçeci, G. (2017). Makro sosyal hizmet uygulamasında kullanılan modeller, teknikler ve sosyal hizmet uzmanlarınin rolleri. Toplum ve Sosyal Hizmet, 28(1), 187-202.

Koçak, O., Kavi, E. ve Es, M. (2017). Bilgi toplumu perspektifinde refah devleti: Finlandiya Modeli. Yalova Üniversitesi Sosyal Bilimler Dergisi, 7(13), 48-75.

Koray, M. (2003). Avrupa refah devleti: Anlamı, boyutları ve geleceği. Görüş Dergisi, 57(1), 70-101.

Kuisma, M. (2007). Social democratic internationalism and the welfare state after the 'golden age'. Cooperation and Conflict: Journal of the Nordic International Studies Association, 42(1), 9-26.

Kurt, Ş. (2006). İşsizliğin psiko-sosyal sonuçları ve Türkiye üzerine muhtemel etkileri. Sosyal Siyaset Konferansları Dergisi, 51, 357-379.

Leibfried, S. (1993). Towards a European welfare state. İçinde: C. Jones (Ed.). New Perspectives on the Welfare State in Europe, (First ed., ss. 120-144). London: Routledge Press.

Leibfried, S. (2000). National welfare states, European integration and globalization: A perspective for the next century. Social Policy \& Administration, 34(1), 44-63.

Leibfried, S. ve Obinger, H. (2003). The state of the welfare state: German social policy between macroeconomic retrenchment and microeconomic recalibration. West European Politics, 26(4), 199-218.

Lorenz, W. (2005). Social work and a new social order-challenging neoliberalism's erosion of solidarity. Social Work \& Society, 3(1), 93101.

Manning, N. (2003). Welfare, ideology and social teory. İçinde: J. Baldock, N. Manning ve S. Vickerstaff (Eds.). Social Policy (2nd ed., ss. 5278). Oxford: Oxford University Press.

Marangoz, Ş. (2001). Refah devleti: Gelişimi, oluşumu, modelleri ve güncel değişimler. Yüksek lisans tezi, İstanbul Üniversitesi, İstanbul.

Mishra, R. (1999). Globalization and the welfare state. UK: Edward Elgar Publishing.

Misra, J. ve Akins, F. (1998). The welfare state and women: Structure, agency, and diversity. Social Politics: International Studies in Gender, State \& Society, 5(3), 259-285. 
Myles, J. ve Quadagno, J. (2002). Political theories of the welfare state. Social Service Review, 76(1), 34-57.

Özalp, L. F. A. (2016). İktisatta refah ve refah devletinin iktisadi analizi. Doktora tezi, İstanbul Üniversitesi, İstanbul.

Özdek, Y. (2002). Küresel yoksulluk ve küresel şiddet kıskacında insan hakları. Yoksulluk, Şiddet ve İnsan Hakları, 1-44. Ankara: TODAİE, Yayın No.311. 25 Kasım 2018 tarihinde http://sendika62.org/arsiv/yozdek1-2009-04-12.pdf web adresinden erişildi.

Özdemir, S. (2004). Küreselleşme sürecinde refah devleti. Doktora tezi, İstanbul Üniversitesi, İstanbul.

Pfau-Effinger, B. (2005). Welfare state policies and the development of care arrangements. European Societies, 7(2), 321-347.

Pierson, C. (1998). Contemporary challenges to welfare state development. Political Studies, 46(4), 777-794.

Pringle, K. (1998). Europe and social welfare. İçinde: K. Pringle (Ed.). Children and Social Welfare in Europe (First ed., pp.1-19). Buckingham: Open University Press.

Sharkh, M. A. ve Gough, I. (2010). Global welfare regimes: A cluster analysis. Global Social Policy, 10(1), 27-58.

Smith, D. (2000). Welfare and work. İçinde: D. Smith (Ed.). Welfare, Work and Poverty: Lessons from Recent Reforms in the USA and the UK (First published, 23-32). London: The Cromwell Press.

Soyseçkin, İ. (2015). Türkiye'de kadın istihdamı ve sosyal refah uygulamaları. Mülkiye Dergisi, 39(3), 245-270.

Sözer, A. N. (1997). Sosyal devlet uygulamaları. Ankara: Türkiye İşçi Emeklileri Cemiyeti Yayını.

Spicker, P. (2000). The welfare state: A general theory (First published). London: SAGE.

Stephens, J. D. (1996). The Scandinavian welfare states: Achivements, crisis and prospects. İçinde: G. Esping-Andersen (Ed.). Welfare State in Transition: National Adaptations in Global Economics (First published, ss. 32-65). London: Sage Publications.

Şahin, F. (2000). Sosyal hizmet uzmanlarının sosyal refah politikası süreçlerine katılımı. Ankara: Aydınlar Matbaası.

Şener, Ü. (2012). Kadın yoksulluğu. Mülkiye Dergisi, 36(4), 51-67. 
Şener, Ü. (2009). Kadın yoksulluğu. (TEPAV Değ. Notu), 25 Kasım 2018 tarihinde http://www.tepav.org.tr/upload/files/1271312994r5658.Kadin_Yoksullugu.pdf web adresinden erişildi.

Tekindal, M. (2018). Türkiye'de sosyal yardımların yapısal işlevsel yaklaşıma göre analizi. Toplum ve Sosyal Hizmet, 29(2), 335-362.

Titmuss, R. M. (1974). Social policy: An introduction. New York: Pantheon Books.

Toprak, D. (2015). Uygulamada ortaya çıkan farklı refah devleti modelleri üzerine bir inceleme. Süleyman Demirel Üniversitesi Sosyal Bilimler Enstitüsü Dergisi, 21(1), 151-175.

Tuncay, T. ve Yıldırım, B. (2015). Factors affecting the psychological distress among unemployed and re-employed individuals. Career Development International, 20(5), 482-502.

Vesali, S. ve Omidi, R. (2014). Social policy: Themes and approaches. The Journal of Planning \& Budgeting, 19(1), 179-206.

Zengin, O. ve Çalış, N. (2017). Sosyal hizmet uzmanlarının mesleki uygulamaları ve çalışma koşulları. Toplum ve Sosyal Hizmet, 28(1), 47-68. Zengin, O. ve Altındağ, Ö. (2013). Refah yaklaşımından çalıştırmacı yaklaşıma doğru. İçinde: Ş. Hacıyev (Ed.). The World Economic Development Paradigm: Market and Beyond (First ed., pp.252-263). Baku: Azerbaijan State Economic University Press.

\section{Kaynakça Bilgisi / Citation Information}

Yıldırım, B. ve Şahin F. (2019). Esping-Andersen'in refah devleti siniflandırması ve makro sosyal hizmet uygulamaları temelinde Türkiye'nin konumu. OPUS-Uluslararası Toplum Araştırmaları Dergisi, 11(18), 2525-2554. DOI: 10.26466/opus. 542395 